\section{Cureus}

\title{
Laryngeal Squamous Cell Carcinoma Survival in the Context of Human Papillomavirus: A Systematic Review and Meta-analysis
}

\author{
Navid Ahmadi ${ }^{1}$, Nima Ahmadi ${ }^{2}$, Michael V. Chan ${ }^{3}$, Ya Ruth Huo ${ }^{1}$, Niranjan Sritharan ${ }^{4}$, Ronald Chin ${ }^{5}$ \\ 1. Faculty of Medicine, UNSW 2. Colorectal Surgery, Royal Prince Alfred Hospital 3. Department of Radiology, \\ Concord Hospital 4. ENT Department, Nepean Hospital, Kingswood, AUS 5. ENT Department, St. George Hospital, \\ University of Sydney, Sydney, AUS
}

$\square$ Corresponding author: Navid Ahmadi,dr.ahmadi.navid@gmail.com

Disclosures can be found in Additional Information at the end of the article

\section{Abstract}

Background: Head and neck (H\&N) squamous cell carcinoma (SCC) is a significant contributor to worldwide mortality and morbidity. Human papillomavirus (HPV) has been linked with H\&N cancer and HPV-positive H\&N SCC have been shown to have better survival outcomes.

Objective: To evaluate the effect of human papillomavirus (HPV) on laryngeal carcinoma (LSCC) survival outcomes and prognosis.

Method: A systematic review and meta-analysis were performed using the Preferred Reporting Items for Systematic Reviews and Meta-Analyses (PRISMA) guidelines. LSCC was confirmed based on histopathology, and HPV status was confirmed by either polymerase chain reaction, immunohistochemistry, and/or in-situ hybridization.

Results: There were 1214 studies which were identified, of which 14 studies were eligible for our review. A total of 2,578 cases of LSCC were included in analysis with 413 (16.0\%) HPV-positive. Overall survival (OS) was not significant for HPV-positive LSCC in first five years (year one: OR $1.44 \mathrm{p}=0.13$; year two: OR 1.24 $\mathrm{p}=0.30$; year three: OR $1.01 \mathrm{p}=0.97$; year four: OR $1.13 \mathrm{p}=0.63$; year five: OR $1.01 \mathrm{p}=0.98$ ). Disease-free survival (DFS) was similarly not significant for HPV-positive LSCC (year one: OR $1.08 \mathrm{p}=0.68$; year two: OR 1.22, $\mathrm{p}=0.31$; year three: OR $1.13, \mathrm{p}=0.69$; year four: OR $0.93, \mathrm{p}=0.80$ and year five: OR $1.42, \mathrm{p}=0.30$ ). When studies are sub-divided into global regions, Chinese studies had better HPV-positive survival compared to North American studies in year five (OR 1.84 vs OR 0.46, $\mathrm{p}=0.04$ ).

Conclusion: This is the first study of its kind to evaluate the survival impact of HPV-positive LSCC patients. Unlike oropharyngeal cancer, HPV status does not make a difference to OS or DFS in LSCC. This supports data that HPV is not a prognostic factor in squamous carcinoma of the larynx.

Received 01/27/2018

Review began 02/07/2018 Review ended 02/19/2018 Published 02/26/2018

\section{(C) Copyright 2018}

Ahmadi et al. This is an open access article distributed under the terms of the Creative Commons Attribution License CCBY 3.0., which permits unrestricted use, distribution, and reproduction in any medium, provided the original author and source are credited.
Categories: Otolaryngology, Radiation Oncology, Oncology

Keywords: human papilloma virus (hpv), scc (squamous cell cancer), larynx, laryngeal cancer, overall survival, survival outcome, oropharynx, head and neck cancer, orophahryngeal cancer

\section{Introduction}

Squamous cell carcinoma of the head and neck is a significant contributor to worldwide morbidity and mortality. There are more than 500,000 new cases worldwide reported annually [1]. Laryngeal squamous cell carcinoma (LSCC) is the second most common head and neck malignancy worldwide with 151,000 new cases per year worldwide [2-3]. While there is a great amount of evidence that suggests alcohol and tobacco are causative agents in developing LSCC, there are increasing incidences of LSCC in non-smokers and non-drinkers [4-6].

There is great variation in reporting the incidence of HPV-positive LSCC in literature, however, a recent meta-analysis reports incidence at roughly $25 \%$ with minor variation depending on methods of testing [7].

How to cite this article

Ahmadi N, Ahmadi N, Chan M V, et al. (February 26, 2018) Laryngeal Squamous Cell Carcinoma Survival in the Context of Human Papillomavirus: A Systematic Review and Meta-analysis. Cureus 10(2): e2234. DOI 10.7759/cureus.2234 
While it is regarded that HPV-positive oropharyngeal squamous carcinoma has better survival outcomes, there is no evidence the same holds true for LSCC.

The aim of this study is to conduct a systematic review and meta-analysis to evaluate and quantify the effect of human papillomavirus (HPV) on survival outcome of LSCC and to assess regional variation across the globe.

\section{Materials And Methods}

\section{Search strategy and selection criteria:}

Using the Preferred Reporting Items for Systematic Reviews and Meta-analysis (PRISMA) guidelines, this study was conducted [8]. Electronic search of Medline, Embase, Cochrane Methodology Register, Cochrane Database of Systematic Reviews, Cochrane Central Register of Controlled Trials, Database of Abstracts of Reviews and Effectiveness, ACP Journal Club, and NHS Economic Evaluation Database was conducted from their respective conception to January 2017.

Utilising both MeSH terms and keywords, the search was conducted to ensure ideal sensitivity. The terms "larynx", "squamous cell carcinoma" and "human papilloma virus (HPV)" along with their relevant variations were used. Relevant studies were identified by two independent reviewers (Na.A. and Ni.A.) and were extracted for further evaluations.

Inclusion criteria included histologically confirmed LSCC and HPV-DNA or p16 status was confirmed by polymerase chain reaction (PCR), immunohistochemistry (IHC), and/or in-situ hybridization (ISH). Studies were excluded if they did not provide overall survival (OS) or disease-free survival (DFS) comparing HPVpositive and HPV-negative LSCC. Search was limited to papers with minimum length of follow up of one year, English language, and human subjects. Abstracts, case-reports, conference presentation and any papers without original data were excluded.

\section{Data extraction and critical appraisal:}

Two independent investigators (Na.A. and Ni.A.) extracted data, with discrepancies between reviewers resolved by consensus. The senior investigators (N.S. and R.C.) reviewed final results.

\section{Statistical analysis:}

Meta-analysis was performed with Review Manager (Version 5.3. Copenhagen: The Nordic Cochrane Centre, The Cochrane Collaboration, 2014) using pooled OS and DFS of HPV-positive and HPV-negative LSCC [9]. Data was pooled using the DerSimionian and Laird's random effect model at one, two, three, four, and five years post-diagnosis [10]. To assess publication bias, Egger's linear regression test was utilized and heterogeneity was assessed and quantified using the $\mathrm{I}^{2}$ statistics to measure percentage variability among summary indices [11-12]. Statistical significance was set at 0.05 .

\section{Results}

Through the search of the nine databases, 1214 studies were identified. After excluding studies with duplicated cohorts, irrelevant studies, and studies with data not extractable, 14 studies were analyzed for statistical analysis. All the studies were case-control with two prospective studies, while the remaining 12 were retrospective. Bias was assessed using Egger's test for publication bias and no publication bias was identified [11]. PRISMA guideline study selection is shown in Figure 1, with a description of studies in Table 1. 


\section{Cureus}
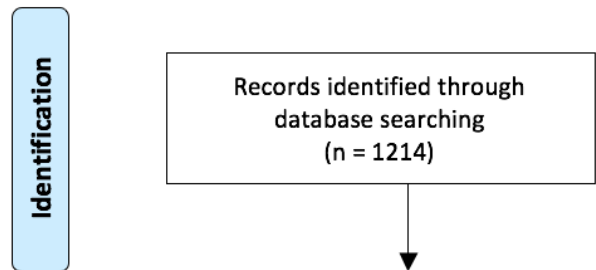

through other sources tabase searching

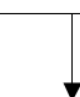

Records after duplicates removed ( $n=866$ )
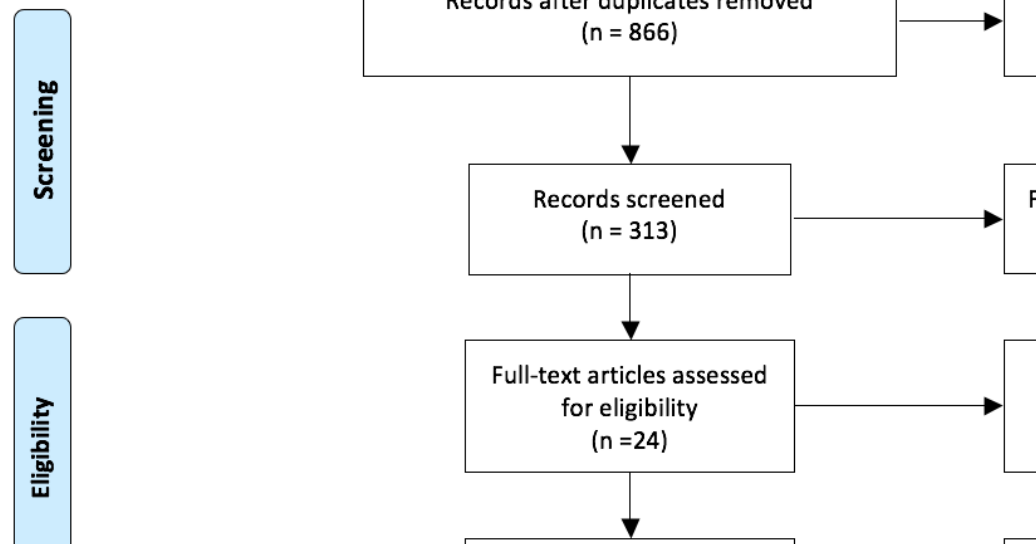

Full-text articles excluded ( $n=289$ )

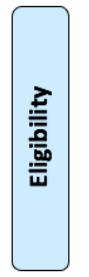
cohort excluded ( $n=7)$
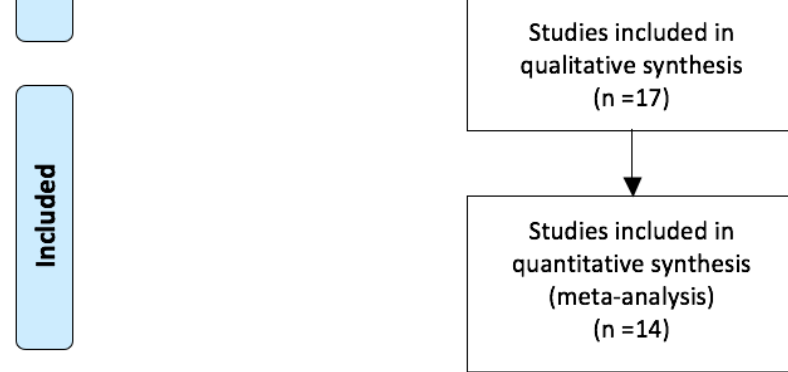

Duplicate cohort excluded ( $n=3)$

\section{FIGURE 1: PRISMA Flow Diagram}

From: Moher D, Liberati A, Tetzlaff J, Altman DG, The PRISMA Group (2009). Preferred Reporting Items for Systematic Reviews and Meta-Analyses: The PRISMA Statement. PLoS Med 6(7): e1000097. doi:10.1371/journal.pmed1000097 


\section{Cureus}

\begin{tabular}{|c|c|c|c|c|c|c|c|c|c|c|}
\hline Author & Year & Country & $\mathbf{n}$ & $\begin{array}{l}\text { Study } \\
\text { Period }\end{array}$ & $\begin{array}{l}\text { Study } \\
\text { Design }\end{array}$ & Prospective & $\begin{array}{l}\text { Detection of } \\
\text { HPV }\end{array}$ & Sample & p16 & $\begin{array}{l}\text { HPV } \\
\text { DNA }\end{array}$ \\
\hline $\begin{array}{l}\text { Rivera- } \\
\text { Pena }\end{array}$ & 2016 & $\begin{array}{l}\text { USA (Puerto } \\
\text { Rico) }\end{array}$ & 83 & 1993-2005 & Case-control & Retrospective & PCR & FF & NR & $\mathrm{Y}$ \\
\hline Hernandez & 2016 & USA & 101 & 1993-2004 & Case-control & Retrospective & $\mathrm{IHC}$ & PE & $\mathrm{Y}$ & NR \\
\hline Atighechi & 2016 & Iran & 44 & 2007-2012 & Case-control & Retrospective & PCR & PE & NR & $\mathrm{Y}$ \\
\hline Young & 2015 & Australia & 307 & 2002-2012 & Case-control & Retrospective & IHC, ISH & PE & $\mathrm{Y}$ & $\mathrm{Y}$ \\
\hline Wang & 2015 & USA & 356 & 1995-2009 & Case-control & Retrospective & PCR, IHC & PE & $\mathrm{Y}$ & $\mathrm{Y}$ \\
\hline Larque & 2015 & Spain & 45 & NR & Case-control & Retrospective & PCR, IHC & FF, PE & $\mathrm{Y}$ & $\mathrm{Y}$ \\
\hline $\mathrm{Xu}$ & 2014 & China & 674 & 2006-NR & Case-control & Prospective & $\mathrm{IHC}$ & FF, PE & $\mathrm{Y}$ & $\mathrm{Y}$ \\
\hline Lassen & 2014 & Denmark & 479 & 1992-2012 & Case-control & Retrospective & $\mathrm{IHC}$ & PE & $\mathrm{Y}$ & NR \\
\hline Chung & 2014 & Multicentre & 181 & NR & Case-control & Prospective & IHC, ISH & PE & $\mathrm{Y}$ & NR \\
\hline Jiang & 2013 & China & 71 & 1997-2008 & Case-control & Retrospective & IHC, ISH & PE & NR & NR \\
\hline Stephen & 2012 & USA & 79 & NR & Case-control & Retrospective & PCR & PE & NR & $\mathrm{Y}$ \\
\hline Duray & 2010 & Belgium & 67 & 2001-2007 & Case-control & Retrospective & PCR, IHC & PE & $\mathrm{Y}$ & $\mathrm{Y}$ \\
\hline Morshed & 2010 & Poland & 93 & 1999-2002 & Case-control & Retrospective & PCR, IHC & PE & NR & $\mathrm{Y}$ \\
\hline Clayman & 1994 & USA & 78 & $\begin{array}{l}\text { Prior to } \\
1989\end{array}$ & Case-control & Retrospective & PCR & PE & NR & Y \\
\hline
\end{tabular}

\section{TABLE 1: Description of Studies Utilized in this Meta-analysis.}

NR - not recorded, ISH - In-situ hybridization, PCR - polymerase chain reaction, IHC - Immunohistochemistry, PE - paraffin embedded, FF - fresh frozen

Overall, 2578 LSCC cases were included in this analysis with 413 (16.0\%) cases positive for HPV with 2051 (91.6\%) male. HPV rates differed greatly between regions, as is summarised in Table 2 . There was no difference noted in terms of OS of HPV-positive male (OR 0.63, 95\% CI 0.20-1.92, $\mathrm{p}=0.41, \mathrm{I}^{2}=75 \%$ ). Majority of LSCC were smokers ( $\mathrm{n}=1252,85.6 \%)$ and alcohol drinkers ( $\mathrm{n}=703,61.1 \%)$. Also, most of LSCC were well differentiated (61.2\%) and only the minority were poorly differentiated (15.7\%). In terms of tumor classification, there was an even spread between the grades (T1: 27.6\%, T2: 22.1\%, T3: 35.4, T4: 14.9\%). Most of the LSCC had no regional node involvement (58.6\%). Most patients were treated with the combination of radiotherapy and/or chemotherapy (42.4\%), while $30.9 \%$ had surgery alone and $26.7 \%$ had surgery with chemotherapy and/or radiotherapy (Table 3). 


\section{Cureus}

\begin{tabular}{|c|c|c|c|c|}
\hline Author & Year & $\mathbf{n}$ & HPV + & HPV - \\
\hline \multicolumn{5}{|l|}{ CHINA } \\
\hline Jiang & 2013 & 71 & $31(43.7 \%)$ & $40(56.3 \%)$ \\
\hline $\mathrm{Xu}$ & 2014 & 674 & $33(4.9 \%)$ & $641(95.1 \%)$ \\
\hline \multirow[t]{2}{*}{ Wang } & 2015 & 318 & $42(13.2 \%)$ & $276(86.8 \%)$ \\
\hline & Total & 1063 & $106(10.0 \%)$ & $957(90.0 \%)$ \\
\hline \multicolumn{5}{|l|}{ EUROPE } \\
\hline Morshed & 2010 & 93 & $33(35.5 \%)$ & $60(64.5 \%)$ \\
\hline Duray & 2010 & 59 & $44(74.6 \%)$ & $15(25.4 \%)$ \\
\hline Lassen & 2014 & 479 & $65(13.6 \%)$ & $414(86.4 \%)$ \\
\hline \multirow[t]{2}{*}{ Larque } & 2015 & 45 & $4(8.9 \%)$ & $41(91.1 \%)$ \\
\hline & Total & 676 & $146(21.6 \%)$ & $530(78.4 \%)$ \\
\hline \multicolumn{5}{|c|}{ NORTH AMERICA \& CENTRAL AMERICA } \\
\hline Clayman & 1994 & 65 & $30(46.2 \%)$ & $35(53.8 \%)$ \\
\hline Stephen & 2012 & 77 & $21(27.3 \%)$ & $56(72.7 \%)$ \\
\hline Hernandez & 2016 & 101 & $8(7.9 \%)$ & $93(92.1 \%)$ \\
\hline \multirow[t]{2}{*}{ Rivera-Pena } & 2016 & 83 & $41(49.4 \%)$ & $42(50.6 \%)$ \\
\hline & Total & 326 & 100 (30.7\%) & 226 (69.3\%) \\
\hline \multicolumn{5}{|l|}{ OTHERS } \\
\hline Chung & 2014 & 181 & $31(17.1 \%)$ & 150 (82.9\%) \\
\hline Young & 2015 & 288 & $19(6.6 \%)$ & 269 (93.4\%) \\
\hline \multirow[t]{2}{*}{ Atighechi } & 2016 & 44 & $11(25.0 \%)$ & $33(75.0 \%)$ \\
\hline & Total & 513 & $61(11.9 \%)$ & 452 (88.1\%) \\
\hline
\end{tabular}

\section{TABLE 2: Breakdown of HPV Incidence Based on Region of the World}

HPV - Human Papillomavirus 


\section{Cureus}

\begin{tabular}{|c|c|c|c|c|c|c|c|c|c|c|c|c|c|c|c|c|c|c|c|}
\hline & & & & & & & & & & erentiation & $\begin{array}{l}\text { Nodal } \\
\text { Metastasis }\end{array}$ & Location & & & Treatment & & & & \\
\hline Author & Year & $\mathrm{n}$ & $\begin{array}{l}\text { HPV } \\
+\mathrm{ve}\end{array}$ & $\begin{array}{l}\text { HPV - } \\
\text { ve }\end{array}$ & $\begin{array}{l}\text { Mean } \\
\text { Age }\end{array}$ & $\begin{array}{l}\text { Age } \\
\text { Range }\end{array}$ & $\begin{array}{l}\text { Male } \\
(\%)\end{array}$ & $\begin{array}{l}\text { Smoker } \\
(\%)\end{array}$ & $\begin{array}{l}\text { Alcohol } \\
\text { Drinker } \\
(\%)\end{array}$ & Well-Moderate & Poor & No & $\mathrm{N}+$ & $\begin{array}{l}\text { Supra- } \\
\text { glottis }\end{array}$ & Glottis & $\begin{array}{l}\text { Sub- } \\
\text { glottis }\end{array}$ & $\begin{array}{l}\text { Surgery } \\
\text { alone }\end{array}$ & $\begin{array}{l}\text { Surgery } \\
+C R T\end{array}$ & CRT \\
\hline $\begin{array}{l}\text { Rivera- } \\
\text { Pena }\end{array}$ & 2016 & 83 & 41 & 42 & NR & $N R$ & NR & NR & NR & NR & $\mathrm{NR}$ & NR & NR & $\mathrm{NR}$ & $\mathrm{NR}$ & $\mathrm{NR}$ & $\mathrm{NR}$ & NR & NR \\
\hline Hernandez & 2016 & 101 & 8 & 93 & NR & NR & NR & NR & NR & NR & NR & NR & NR & NR & NR & NR & NR & NR & NR \\
\hline Atighechi & 2016 & 44 & 11 & 33 & 57.8 & NR & 90.9 & $\mathrm{NR}$ & $\mathrm{NR}$ & NR & NR & $\mathrm{NR}$ & $\mathrm{NR}$ & NR & NR & NR & NR & NR & NR \\
\hline Young & 2015 & 288 & 19 & 269 & $66^{*}$ & $36-88$ & 93.9 & 88.2 & $\mathrm{NR}$ & NR & NR & 213 & 94 & 102 & 180 & 16 & NR & 95 & 207 \\
\hline Wang & 2015 & 318 & 42 & 276 & $59^{*}$ & $32-87$ & 98.1 & 86.1 & 41.5 & 282 & 36 & 290 & 28 & NR & NR & NR & 228 & 90 & NR \\
\hline Larque & 2015 & 45 & 4 & 41 & 65 & NR & 100.0 & NR & $\mathrm{NR}$ & 17 & 28 & $\mathrm{NR}$ & $\mathrm{NR}$ & 13 & 12 & 16 & NR & NR & NR \\
\hline $\mathrm{Xu}$ & 2014 & 674 & 33 & 641 & NR & NR & 97.0 & $82.9 \%$ & 65.0 & NR & NR & 363 & 311 & 172 & 461 & 31 & 320 & 354 & NR \\
\hline Lassen & 2014 & 479 & 65 & 414 & NR & NR & 81.0 & NR & NR & NR & NR & 156 & 232 & NR & NR & NR & NR & NR & NR \\
\hline Chung & 2014 & 181 & 31 & 150 & NR & NR & NR & NR & $\mathrm{NR}$ & NR & NR & NR & NR & 126 & 50 & 5 & NR & NR & NR \\
\hline Jiang & 2013 & 71 & 31 & 40 & 61.6 & NR & 97.2 & NR & NR & 60 & 11 & 50 & 21 & 32 & 39 & NR & 32 & 39 & NR \\
\hline Stephen & 2012 & 77 & 21 & 56 & NR & NR & 75.3 & 94.8 & 97.0 & 61 & 15 & NR & NR & 28 & 28 & 1 & 26 & NR & 51 \\
\hline Duray & 2010 & 59 & 44 & 15 & NR & NR & 97.0 & NR & NR & 66 & 1 & 56 & 11 & 15 & 35 & NR & 67 & NR & NR \\
\hline Morshed & 2010 & 93 & 33 & 60 & NR & NR & 83.9 & 87.9 & 74.7 & 79 & 14 & 49 & 44 & 54 & 35 & 4 & NR & NR & NR \\
\hline Clayman & 1994 & 65 & 30 & 35 & 60 & NR & 83.1 & NR & NR & NR & NR & NR & NR & NR & NR & NR & 22 & 23 & 23 \\
\hline Total & & 2578 & $\begin{array}{l}413 \\
(16.0 \%)\end{array}$ & $\begin{array}{l}2165 \\
(84.0 \%)\end{array}$ & - & - & 91 & 85.6 & 61.1 & $565(84.3 \%)$ & $\begin{array}{l}105 \\
(15.7 \%)\end{array}$ & $\begin{array}{l}1177 \\
(61.4 \%)\end{array}$ & $\begin{array}{l}741 \\
(38.6 \%)\end{array}$ & $\begin{array}{l}542 \\
(37.3 \%)\end{array}$ & $\begin{array}{l}840 \\
(57.7 \%)\end{array}$ & $\begin{array}{l}73 \\
(5.0 \%)\end{array}$ & $\begin{array}{l}695 \\
(44.1 \%)\end{array}$ & $\begin{array}{l}601 \\
(38.1 \%)\end{array}$ & $\begin{array}{l}281 \\
(17.8 \%)\end{array}$ \\
\hline
\end{tabular}

\section{TABLE 3: Demographics of studies involved in Meta-analysis}

NR - Not Recorded.

N0 - no nodal metastasis

$\mathrm{N}+$ - nodal metastasis

CRT - combination of chemotherapy and/or radiotherapy.

${ }^{*}$ median age,

In terms of survival, there was no difference noted in terms of OS in the first five years post-diagnosis (Figure 2). However, from year three to five post-diagnosis, there was a significant heterogeneity noted between studies (year three: $\mathrm{I}^{2}=46 \%$, year four: $\mathrm{I}^{2}=57 \%$, year five: $\mathrm{I}^{2}=66 \%$ ). Similarly, there is no difference noted in DFS in the first five years post-diagnosis. There is also significant heterogeneity in third- and fifth-year post-diagnosis (year 3: $\mathrm{I}^{2}=62 \%$, year 5 : $\mathrm{I}^{2}=64 \%$ ). Similarly, there was no significance between DFS in the context of HPV (Figure 3). 


\section{Cureus}

a)

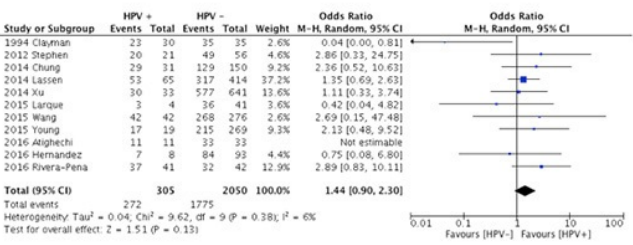

b)
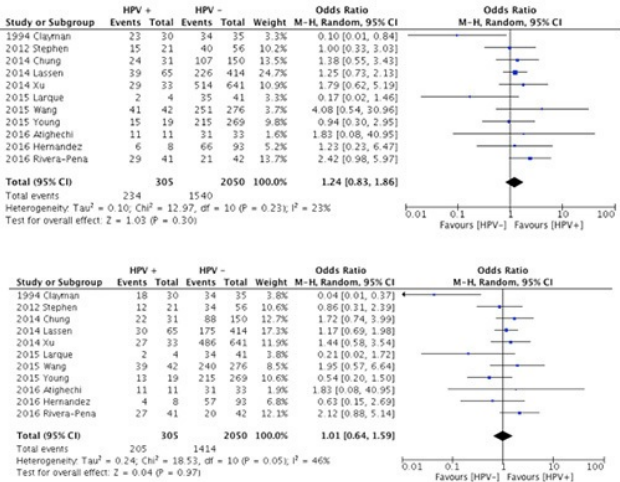

d)

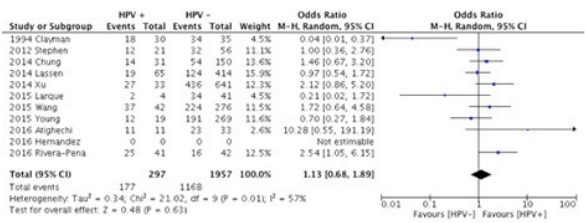

e)

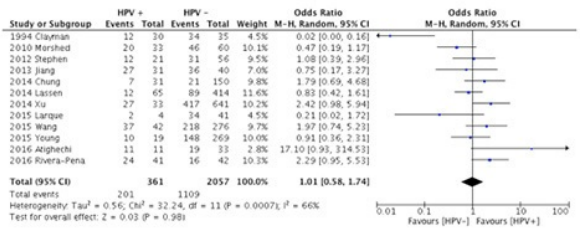

FIGURE 2: Forest plot comparing overall survival (OS) comparing HPVpositive LSCC to HPV-negative LSCC

a - year 1, b - year 2, c - year 3, d - year 4, e - year 5

LSCC - Laryngeal Squamous Cell Carcinoma 


\section{Cureus}
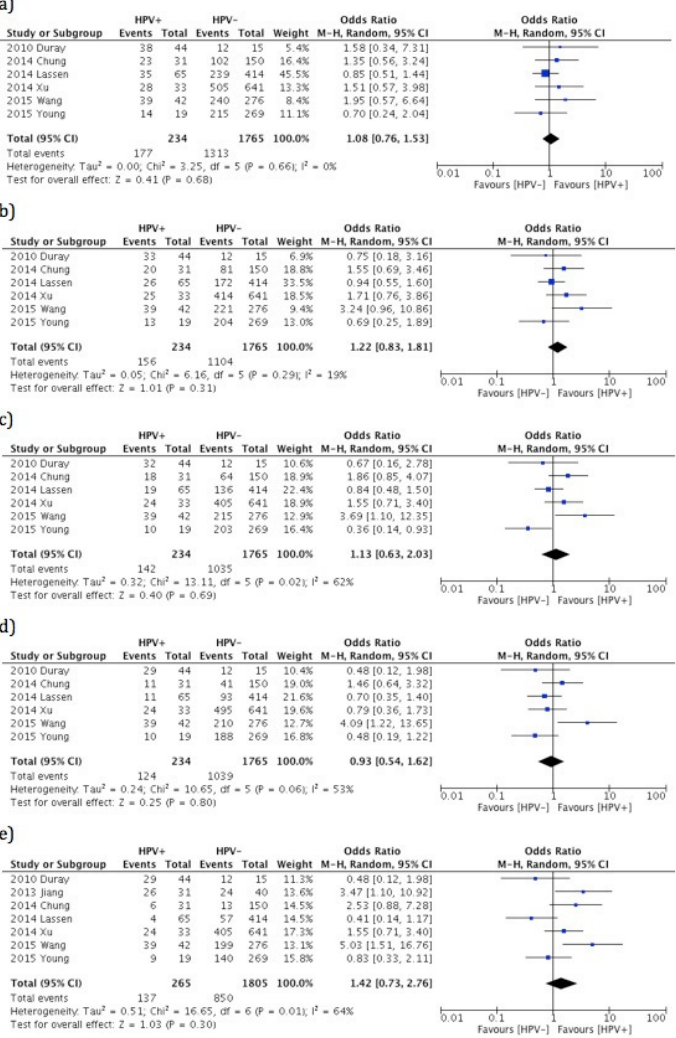

\section{FIGURE 3: Forest plot comparing disease-free survival (DFS) comparing HPV-positive LSCC to HPV-negative LSCC}

a - year 1, b - year 2, c - year 3, d - year 4, e - year 5

LSCC - Laryngeal Squamous Cell Carcinoma

When OS is stratified based on location, studies from China show better OS of HPV-positive LSCC in fourth and fifth-year post-diagnosis ( $\mathrm{OR}=1.92, \mathrm{p}=0.05$, and $\mathrm{OR}=1.84, \mathrm{p}=0.05$ respectively) compared to North America in the same year $(\mathrm{OR}=0.63, \mathrm{p}=0.39$, and $\mathrm{OR}=0.46, \mathrm{p}=0.48)$. This demonstrates a significant difference noted between the regions in fifth-year post-diagnosis ( $\mathrm{p}=0.04)$. Looking at heterogeneity within regions, there is a significant heterogeneity noted in third- to fifth-year post-diagnosis $(\mathrm{p}=0.05$, $\mathrm{p}=0.01$, and $\mathrm{p}<0.01$ respectively). The results are summarised in Table 4 .

\begin{tabular}{|c|c|c|c|c|c|c|}
\hline Regions & No. of studies & OR & $95 \% \mathrm{Cl}$ & p-value & $I^{2}$ & Hetrogeneity (p-value) \\
\hline \multicolumn{7}{|l|}{ Year 1} \\
\hline China & 2 & 1.27 & $0.41-3.88$ & 0.68 & $0 \%$ & 0.57 \\
\hline Europe & 2 & 1.25 & $0.65-2.37$ & 0.50 & $0 \%$ & 0.36 \\
\hline N. America \& C. America & 4 & 0.97 & $0.18-5.18$ & 0.97 & $63 \%$ & $0.04^{*}$ \\
\hline Others & 3 & 2.24 & $0.78-6.48$ & 0.14 & $0 \%$ & 0.93 \\
\hline
\end{tabular}




\section{Cureus}

Between Subgroups

Year 2

China

$\begin{array}{lllll}2.14 & 0.83-5.49 & 0.11 & 0 \% & 0.47 \\ 0.61 & 0.09-3.96 & 0.61 & 68 \% & 0.08 \\ 0.96 & 0.32-2.87 & 0.95 & 61 \% & 0.05^{*} \\ 1.21 & 0.61-2.43 & 0.59 & 0 \% & 0.85 \\ & & 0.57 & 23 \% & 0.23\end{array}$

Between Subgroups

Europe

N. America \& C. America

Others

Year 3

China

Europe

N. America \& C. America

Others

Between Subgroups

Year 4

China

Europe

N. America \& C. America

Others

Between Subgroups

Year 5

China

Europe

N. America \& C. America

Others

Between Subgroups
2

3

2

2

4

3

2

2

3

3

3

3

$\begin{array}{lllll}1.60 & 0.77-3.31 & 0.21 & 0 \% & 0.69 \\ 0.67 & 0.14-3.29 & 0.63 & 59 \% & 0.12 \\ 0.62 & 0.17-2.20 & 0.46 & 75 \% & <0.01 \\ 1.07 & 0.44-2.57 & 0.89 & 35 \% & 0.22 \\ & & 0.54 & 46 \% & 0.05^{*}\end{array}$

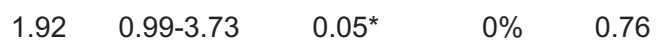

$\begin{array}{lllll}0.63 & 0.16-2.44 & 0.51 & 47 \% & 0.17\end{array}$

$\begin{array}{lllll}0.63 & 0.10-3.78 & 0.61 & 85 \% & <0.01^{*}\end{array}$

$\begin{array}{lllll}1.28 & 0.68-1.89 & 0.60 & 45 \% & 0.16\end{array}$

$0.3957 \% \quad 0.01^{*}$

$\begin{array}{lllll}1.84 & 1.00-3.36 & 0.05^{*} & 0 \% & 0.41 \\ 0.62 & 0.36-1.08 & 0.09 & 5 \% & 0.35 \\ 0.46 & 0.06-3.86 & 0.48 & 89 \% & <0.01^{*} \\ 1.70 & 0.59-4.93 & 0.33 & 52 \% & 0.13 \\ & & 0.04^{*} & 66 \% & <0.01^{*}\end{array}$

TABLE 4: Breakdown of odds ratio (OR) of HPV-positive LSCC as compared to HPV-negative LSCC subdivided based on global regions

HPV - Human Papillomavirus

LSCC - Laryngeal Squamous Cell Carcinoma

\section{Discussion}

The pathogenesis of HPV and its effect on patient treatment and survival outcomes is an area of great importance in head and neck oncology. This study evaluates the current literature with regards to the pathogenesis of HPV as it relates specifically to laryngeal cancer and suggests that unlike in oropharyngeal 
cancer, HPV in the larynx has little to no effect on survival outcome.

HPV consists of double-stranded DNA genomes with more than 100 genotypes, of which more than 24 genotypes are detected in head and neck cancers [13-17]. HPV produces the malignant transformation of cells by producing E6 and E7 proteins that act together to lock cells in a forward replication phase [18]. As a result, HPV-positive oropharyngeal SCC (OSCC) is different to their HPV-negative counterparts, in that they have different patterns of dissemination and lower incident of metachronous primary tumors [19]. This may explain why HPV-positive OSCC have better responses to chemotherapy and radiotherapy, such that the latest American Joint Committee on Cancer (AJCC) divided staging for OSCC into different categories based in HPV status in the eight edition [20].

HPV has a propensity for tumorigenesis in the tonsillar crypts, which are deep recesses with a discontinuous basement membrane, and vasculature, which may explain the early propensity for lymphovascular invasion and early regional nodal spread [21-22]. This contrasts with laryngeal epithelium which is squamous epithelium with less abundant lymphatics particularly in the glottis [21-22].

While there is a large body of literature looking at HPV in oropharyngeal cancer, little research has focused on laryngeal pathology with regards to HPV. In this study, we demonstrate that there is no difference in survival in the context of OS and DFS based on HPV status. This suggests that HPV is not a significant driver of LSCC, and as such HPV status has limited clinical relevance in LSCC.

Recent meta-analysis by Ndiaye and colleagues showed HPV prevalence of LSCC is $22.1 \%$ (95\% CI 16.4 28.3) while another meta-analysis demonstrated that the prevalence was $26.8 \%$ or $20.3 \%$ depending on whether PCR-testing for HPV was utilized or not [6-7]. This is lower than the incidence of HPV (45.8\%; $95 \%$ CI 38.9-52.9\%) in OSCC in the same study [6]. This demonstrates selective uptake of HPV in oropharynx as compared to larynx, and further suggests that HPV is likely not a strong indicator of LSCC. The prevalence of LSCC in this study (16\%) is lower than the two above-mentioned meta-analyses. This may represent an inherent selection bias, as only studies with survival outcome and HPV status were included. As a result, the external validity of the current literature needs to be questioned in terms of providing accurate survival data on LSCC in context of HPV.

Another explanation for the different prevalence of HPV is the heterogeneity between different regional populations. The prevalence HPV-positive LSCC of Chinese cohort is 10\%, while the prevalence of the rest of the world is $20.3 \%$. While others have shown similar heterogeneity, their reported prevalence is different to our study. Ndiaye, et al. (2014) show the prevalence of HPV is $28.3 \%$ in Asia and $18.8 \%$ in North America, while Gama, et al. (2016) show point estimate of 0.246 (95\%CI: 0.201-0.298) in North America to 0.399 (95\%CI: 0.323-0.479) [6-7]. The lower rates in the Chinese population may, to some extent, account for a higher smoking rate in China, compared to North America.

There was no difference noted between HPV-positive and HPV-negative LSCC in terms OS and DFS. However, there was significant heterogeneity noted in studies. As mentioned previously, the AJCC now considers HPV-positive and HPV-negative OSCC different disease entities [20]. This is because HPVpositive OSCC also has better survival outcomes compared to HPV-negative OSCC [23-25]. However, the same does not seem to follow for LSCC. The difference in HPV prevalence between oropharynx and larynx is still not completely well understood and it is uncertain why HPV affects OSCC and LSCC differently [26].

There is significant regional variation in LSCC survival. This is most pronounced in the fifth year postdiagnosis, where there is a significant difference between the stratified cohorts (Table 4). As mentioned above, $\mathrm{Xu}$, et al. attribute the low prevalence of HPV in Chinese cohorts to high rates of smoking within China which may explain the variability in terms of prevalence and survival of LSCC patients in Chinese cohort [27]. Furthermore, the variability also raises the concern regarding the external validity of various studies performed across the many centers around the world and calls for investigation of the cause of this difference. More molecular and epidemiologic studies are needed to evaluate the relationship of HPV and laryngeal cancers [26].

\section{Limitations}

This meta-analysis is limited by the number of studies with adequate data to allow for sub-analysis of outcomes and further multivariate analysis. There were also a limited number of studies from various 
regions of the world, with North American and Chinese studies accounting for most of the cohort of our meta-analysis. Further research is required to better assess survival outcome of LSCC based on HPV status.

\section{Conclusions}

This is the first meta-analysis to compare HPV-positive LSCC with smoking and alcohol-related LSCC and compare survival outcomes. This is the largest laryngeal meta-analysis looking at survival outcomes in laryngeal SCC with 2578 cases. Even though the study showed heterogeneity across regions in the world, particularly North America and China, the study showed that unlike oropharyngeal squamous cell carcinoma, HPV-positive LSCC does not have a better survival outcome compared to smoking and alcoholrelated LSCC.

\section{Additional Information \\ Disclosures}

Human subjects: Consent was obtained by all participants in this study. Animal subjects: All authors have confirmed that this study did not involve animal subjects or tissue. Conflicts of interest: In compliance with the ICMJE uniform disclosure form, all authors declare the following: Payment/services info: All authors have declared that no financial support was received from any organization for the submitted work. Financial relationships: All authors have declared that they have no financial relationships at present or within the previous three years with any organizations that might have an interest in the submitted work. Other relationships: All authors have declared that there are no other relationships or activities that could appear to have influenced the submitted work.

\section{References}

1. Siegel RL, Miller KD, Jemal A: Cancer statistics, 2015. CA Cancer J Clin. 2015, 65:5-29. 10.3322/caac.21254

2. National Cancer Institute. The Surveillance, Epidemiology, and End Results (SEER) Program . (2018). Accessed: February 23, 2018: http://www.seer.cancer.gov/.

3. Ferlay J, Shin HR, Bray F, et al.: Estimates of worldwide burden of cancer in 2008: GLOBOCAN 2008 . Int J Cancer. 2010, 127:2893-2917. 10.1002/ijc.25516

4. Sankaranarayanan R, Duffy SW, Nair MK, et al.: Tobacco and alcohol as risk factors in cancer of the larynx in Kerala, India. Int J Cancer. 1990, 45:879-882. 10.1002/ijc.2910450517

5. Zatonski W, Becher H, Lissowska J, et al.: Tobacco, alcohol, and diet in the etiology of laryngeal cancer: a population-based case-control study. Cancer Causes Control. 1991, 2:3-10. 10.1007/BF00052355

6. Ndiaye C, Mena M, Alemany L, et al.: HPV DNA, E6/E7 mRNA, and p16INK4a detection in head and neck cancers: a systematic review and meta-analysis. Lancet Oncol. 2015, 15:1319-31. 10.1016/S14702045(14)70471-1

7. Gama RR, Carvalho AL, Longatto Filho A, et al.: Detection of human papillomavirus in laryngeal squamous cell carcinoma: Systematic review and meta-analysis. Laryngoscope. 2016, 126:885-893. 10.1002/lary.25738

8. Moher D, Liberati A, Tetzlaff J, et al.: Preferred reporting items for systematic reviews and meta-analyses: the PRISMA statement. PLoS Med. 2009, 15:264-269. 10.1371/journal.pmed.1000097

9. Cochrane Community: RevMan 5. (2018). Accessed: February 25, 2018: http://community.cochrane.org/tools/review-production-tools/revman-5.

10. DerSimonian R, Laird N: Meta-analysis in clinical trials. Control Clin Trials. 1986, 7:177-188. 10.1016/0197-2456(86)90046-2

11. Egger M, Smith GD, Schneider M, et al.: Bias in meta-analysis detected by a simple, graphical test. BMJ. 1997, 315:629-634. 10.1136/bmj.315.7109.629

12. Higgins JP, Thompson SG, Deeks JJ, et al.: Measuring inconsistency in meta-analyses . BMJ. 2003, 327:557560. 10.1136/bmj.327.7414.557

13. Orth G: Papillomaviruses - human (papovaviridae). Encyclopedia of Virology 2nd Edition. Granoff A, Webster R (ed): Academic Press, San Diego; 1999. 1105-1114. 10.1006/rwvi.1999.0204

14. Orth G, Favre M, Croissant O: Characterization of a new type of human papillomavirus that causes skin warts. J Virol. 1977, 24:108-120.

15. Syrjänen S, Lodi G, von Bültzingslöwen I, et al.: Human papillomaviruses in oral carcinoma and oral potentially malignant disorders: a systematic review. Oral Dis. 2011, 17:58-72. 10.1111/j.16010825.2011.01792.x

16. De Villiers EM, Fauquet C, Broker TR, et al.: Classification of papillomaviruses. Virology. 2004, 324:17-27. 10.1016/j.virol.2004.03.033

17. Coggin Jr JR, zur Hausen H: Workshop on papillomaviruses and cancer. Cancer Res. 1979, 39:545-546.

18. Münger K, Phelps W, Bubb V, et al.: The E6 and E7 genes of the human papillomavirus type 16 together 


\section{Cureus}

are necessary and sufficient for transformation of primary human keratinocytes. J Virol. 1989, 63:44174421.

19. Samuels SE, Eisbruch A, Beitler JJ, et al.: Management of locally advanced HPV-related oropharyngeal squamous cell carcinoma: where are we?. Eur Arch Otorhinolaryngol. 2016, 273:2877-2894.

10.1007/s00405-015-3771-x

20. Lydiatt WM, Patel SG, O'Sullivan B, et al.: Head and neck cancers-major changes in the American Joint Committee on cancer eighth edition cancer staging manual. CA Cancer J Clin. 2017, 67:122-137. 10.3322/caac. 21389

21. Syrjänen S: HPV infections and tonsillar carcinoma. J Clin Pathol. 2004, 57:449-455. 10.1136/jcp.2003.008656

22. Boscolo-Rizzo P, Del Mistro A, Bussu F, et al.: New insights into human papillomavirus-associated head and neck squamous cell carcinoma. Acta Otorhinolaryngol Ital. 2013, 33:77-87.

23. Garnaes E, Frederiksen K, Kiss K, et al.: Double positivity for HPV DNA/p16 in tonsillar and base of tongue cancer improves prognostication: insights from a large population-based study. Int J Cancer. 2016, 139:2598-2605. 10.1002/ijc.30389

24. Rotnáglová E, Tachezy R, Saláková M, et al.: HPV involvement in tonsillar cancer: prognostic significance and clinically relevant markers. Int J Cancer. 2011, 129:101-110. 10.1002/ijc.25889

25. Nordfors C, Grun N, Tertipis N, et al.: CD8+ and CD4+ tumour infiltrating lymphocytes in relation to human papillomavirus status and clinical outcome in tonsillar and base of tongue squamous cell carcinoma. Eur J Cancer. 2013, 49:2522-2530. 10.1016/j.ejca.2013.03.019

26. Chaturvedi AK: Epidemiology and clinical aspects of HPV in head and neck cancers . Head Neck Pathol. 2012, 6:16-24. Accessed: February 25, 2018: 10.1007/s12105-012-0377-0

27. Xu Y, Liu S, Yi H, et al.: Human papillomavirus infection in 674 Chinese patients with laryngeal squamous cell carcinoma.. PLoS One. 2014, 9:e115914. Accessed: February 25, 2018: 10.1371/journal.pone.0115914 